\title{
說苑 アメリカの紡績厂場ね見学して
}

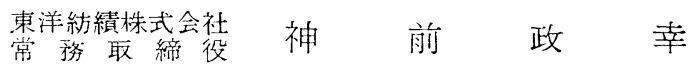

戦後我な゙国の綿業は数次にわたって海外の䛻查団在迎 えた.技術の面こも，アメリカ政府から派遣された E. C. Martin 以下つ Leather Mission や近くは NCCA が編 成した North Carolina State College の Dean M.E.

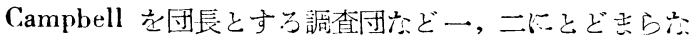
い. 我が国の約縝側からもしばしば使節団や挀查団犬゙派 遣されたな゙,本年 4月 Atrantic City の American Textile Machinery Exhibition 卒㹽会に調查団な゙編成された。 私は乞つ団長として農務省や Memphis の National Cotton Council, New Orleans o S. R. R. Laboratories など20に余っ研究所き大学，9 工場にのぼる紡績及び
加工工場つ公式訪問のほか, 解散後私個人としても多く の工場を見，またカナダや南米も見学する蟣会な゙得た。 この 2 ケ月半にわたる旅行志通じて,アメリカつ工場。 経営, 技術雨面つ特殊生について多くの示晙妾得たこと は誠に幸いだあった。

紡續工場としては第1表に揭げっように，約 116 万鍾 の工場孛見学することがてきた・アメリカつ綿紡鍾数は

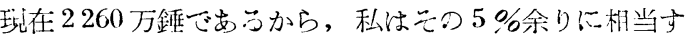

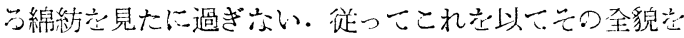
律寸ることは，早棓の誹りを免れないと思うが，自分の 眼に映じ自分て感じたところな主として紡績と織布につ

(第 1 表) 米国で見学した紡績工場

(昭和 29 年 4 月 14 日 $~ 7$ 月 4 日)

\begin{tabular}{|c|c|c|c|}
\hline 名 & 所 & 設 葆 - 製 品 概 要 & 往業具 \\
\hline Wamsutta Mill & $\begin{array}{l}\text { New Bedford, } \\
\text { Mass. }\end{array}$ & 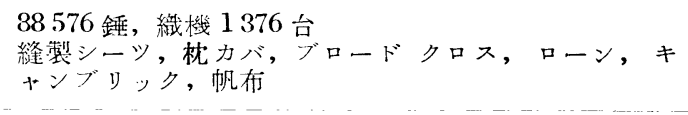 & $\begin{array}{l}3 \text { shit ts } \\
1200 \text { 人 }\end{array}$ \\
\hline $\begin{array}{l}\text { Erwin Mill } \\
\text { Durham Plant }\end{array}$ & Durham, N. C. & $\begin{array}{l}89012 \text { 鍾, 織機 } 1926 \text { 台 } \\
\text { 晒加工, 縫製シーツ, 枕っバ }\end{array}$ & $\begin{array}{l}3 \text { shifts } \\
1200 \text { 人 }\end{array}$ \\
\hline $\begin{array}{l}\text { A.M. Swyre Mfg. } \\
\text { Co. }\end{array}$ & Gastonia, N. C. & $\begin{array}{l}30176 \text { 鍾, 撚糸 } 12570 \text { 鏵 } \\
\text { Cumbed yarn } 18 \text { 's } 20 \text { 's } 30 \text { 's }\end{array}$ & $\begin{array}{l}3 \text { s'uifts } \\
575 \text { 人 }\end{array}$ \\
\hline $\begin{array}{l}\text { Abney Mill } \\
\text { Brandon Plant }\end{array}$ & Greenville, S. C. & 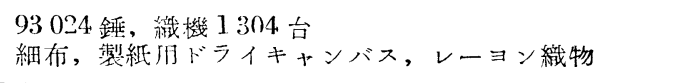 & $\begin{array}{l}3 \text { shi! ts } \\
\text { 不 明 }\end{array}$ \\
\hline $\begin{array}{l}\text { Houston } \\
\text { Texile Mill }\end{array}$ & Houston, Tex. & $\begin{array}{l}7205 \text { 銼, 織機 } 785 \text { 台 } \\
\text { 綿毛布, 最終製品迄 }\end{array}$ & $\begin{array}{l}2 \underset{\text { shifts }}{370 \text { 人 }} \\
\text { 370 }\end{array}$ \\
\hline Woodside Mill & Simpsonville, S. C. & $\begin{array}{l}39792 \text { 鈔, 織機 } 800 \text { 台 } \\
\text { スフ, 等化緎紡績及び織物 }\end{array}$ & $\begin{array}{l}3 \text { shifts } \\
450 \text { 人 }\end{array}$ \\
\hline $\begin{array}{l}\text { F.W. Poe Mfg. } \\
\text { Co. }\end{array}$ & Greenville, S. C. & $\begin{array}{l}58944 \text { 鏵, 織機 } 1534 \text { 台 } \\
\text { 金巾, タバコクロース，ポプリン，コール天, ローン }\end{array}$ & $\begin{array}{l}3 \text { shifts } \\
700 \text { 人 }\end{array}$ \\
\hline Cluett Peabody & $\begin{array}{l}\text { Grosvenor, N. } \\
\text { Conn. }\end{array}$ & $\begin{array}{l}78932 \text { 錘, 織機 } 1300 \text { 台 } \\
\text { ポプリン(白及び編) }\end{array}$ & $\begin{array}{l}3 \text { shilis } \\
1023 \text { 人 }\end{array}$ \\
\hline Dan River Mill & Danville, Va. & 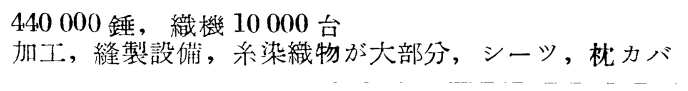 & $\begin{array}{l}3 \text { shift } \\
13000 \text { 人 }\end{array}$ \\
\hline $\begin{array}{l}\text { Joanna Cotton } \\
\text { Mill }\end{array}$ & Joanna, S. C. & $\begin{array}{l}103176 \text { 鏵, 織機 } 2889 \text { 台 } \\
\text { ウインドウ シ ェード クロス }\end{array}$ & $\begin{array}{l}3 \text { shif is } \\
1695 \text { 人 }\end{array}$ \\
\hline $\begin{array}{l}\text { Fulton Rag \& } \\
\text { Cotton Mill }\end{array}$ & Atlanta, Ga. & $\begin{array}{l}81952 \text { 鍾, 織機 } 2074 \text { 台 } \\
\text { 加工縫製設備, 細布, 金巾, オレンジ袋, メリケン袋 } \\
\text { 等 Bag 類, 最終製品加工迄 }\end{array}$ & $\begin{array}{l}3 \text { shifts } \\
3000 \text { 人 }\end{array}$ \\
\hline $\begin{array}{l}\text { Clara Plant ot } \\
\text { Gastonia Combed } \\
\text { yarn Corp. }\end{array}$ & Gastonia, N. C. & $\begin{array}{l}49950 \text { 錘, 撚系 } 12450 \text { 錘 } \\
\text { コームドャー } 20^{\prime} \mathrm{s} \sim 70^{\prime} \mathrm{s} \text { 主として } 30^{\prime} \mathrm{s}\end{array}$ & $\begin{array}{l}3 \text { shif } \text { is } \\
\text { 不 明 }\end{array}$ \\
\hline
\end{tabular}


いて申し述べてみたいと思う。

American Textile Machinery. Association 主催の博 覧会では，世界の紡績技術の粋を眼のあたりに見て，そ の進歩発展の総結集の偉大さに驚嗼した。また北部や南 部の紡績工場つ極めて高い生產性を見て, 最も深い感銘 受けた。即占製品の単位当りの使用人員が非常に少な く, 私が訪れた工場では大体第 2 表のようなもので, 我 が国の半ばという僅少さであった。この高い生產性は果 してどこから来るのであろうか. 以下この点について私 が特に感じたところを申し述べてみたいと思う。

(第 2 表)

アメリカの綿業の单位当り使用人員 （直接，補助管理部門合計）

綿糸: 20 換算 1 梱当り人員 $\cdots 3.0 \sim 4.0$ 人…平均 3.5 人 綿布：天竺 $2 \mathrm{~A}$ 換算 1000

$\mathrm{yd}$ 当 $\eta$ 人員 $\cdots . . . . . .1 .5 \sim 2.5$ 人...平均 2.0 人

\section{原料綿花に惠まれる}

アメリカの綿業は紡機 2260 万錘と織機 43 万台を擁 乙，綿花の消費高忙年間 900 万俵に達与る.昨年 4 月か ら本年 3 月未でに我が国の紡績に割当てられた綿花は, 米綿撸算 235 万余俵であ.るから，その消費は実に我が国 の4倍になんなんとする膨大なるので女る。綿花の収檴 高は国内消費索睄って尔扔かっ 400 万俵程度の輸出余力 を持ち，昨年度の如きはその収穫高は 1646 万余俵に達 し,むしろ綿花の過剩に悩んだほどでもっ・農務省は 8 月 9 目附で本年度綿花の第 1 回収穫予想高を 1268 万俵 と発表した。作付面積の制限によって, 作付反别は前年 比 2 割 1 分も減少して近年まれ飞みる減座が予想される が，950 万俵つ繰越高若考え.と志綿花過剩が解消し ないという国柄でる.従ってアメリカの工場が原料の 面で恵专れていることは当然のととですって，一律にい いうることは，最終製品に最も適した原料を自由に選択 して入手することがご，しかも常に変化がないという ことである。

実際工場心使用している笑情九見てみ.ると,クラスは 殆んどわれわれのものと変りないが，ステープルは確か に 1/16〜1/8 in 長いものを使っている. これはアメリカの 綿系が少なくとも我が国より10\%強く，従って精紡き織 有の系切れが少なく生産性が高いととに大きな影響を与 えている.またネップを一定の範囲に抬さえるために，

Micronaire r使って繊維の Fineness によく注意尼払 っている. Fineness 3.5〜5.5 のもの庄混綿して 4〜5 にしている.我が国で使う米綿の Density は $32 \mathrm{lb} / \mathrm{cuft}$
の High density のものであるが, アメリカの工場では 22 23 lb/cuft のものを多く使っている. 従って Opening や Picking が遥か飞容易である.この点我々 子開俵室で出来.る限り早期に带鉄を切って, 混綿機に投 大する前に十分低いDensity に回復させて招くことが 大切であると思う・高い生產性に寄与している他の要素 は仕掛りの単純化である。

\section{製品の単純化と特色化}

工場の紡績番手や織物の種類が単純で，しかも最終製 品まで一貫して加工されているととは，アメリカの紡績 の大きな特徴である.その製品たるや各社独自の特色を もっている.一例をあげると， South Carolina ともる Joanna Mill (第1 表参照) の如きは, Joanna Western Mills Co. の名のもとに, 全アメリカの空という空の $3 / 4$ 在覆う Window shade を生產している. 紡績釬数 10 万 3000 余錘，織機 2900 台で，Mississippi Delta の高級 原綿を年間 3 万 5000 俵, 明けても暮れても消化し続け ている.またある工場はただ一種類の経系と緯系を，し かも同一原綿から紡績するといったような撤底した操業 をしていた。

単純で特色のある製品を終始一貫して作っているの で, 仕脚りの变更による切替えもなく, 操業は安定し, 従って統一された優れた製品ぶ生産されている. 元来我 が国の綿業は輸出に重点を置き，アメリカの綿業と抢 のずからその本質を異にしているが，現在のような Variety にとむ八百屋式の操業が果して唯一の道でもる かぞうか大いに反省してみる必要がある。また特色の心 い無䭾な辡り合いも極力避くべきだと痛感する。

\section{機械及び設備の合理化}

元来アメリカの紡績の歴史は非常に古く, Columbus の六陸発見当時 (1492年) 既に土民は綿系の綛なバータ に使ったといわれる.1640年頃には英国からの移住者達 が中心となって, New England 地方で紡績をはじめ, との地方はその中心となった・実際の紡績工場が現われ たのは 1789 年 Massachusetts 州の Beverly で, 私が訪 れた同じ州の New BedfordのWamsutta Mill 1846 年の創立であった・とのようと古い歴史をもったアメり カの線紡設備は近年僅かながら淵減の傾向を示してい る. 1943 年と 1952 年を比較してみると, 前者の 24.07 万 鏗に対して後者は 2260 万鉭となり約 $6 \%$ \%㳦少している。 從ってアメリカの多くの工場々決して新しいものではな く, 古い工場が絶えず機械や設備の主要笝所を改造した 
り更新したりして，機械と労敄つ両面に最大の能率をあ げているということができ。その合理化の方向をたず ねてみると次のような諸点があげられる。

\section{(a) 工程の簡素化と連続化}

出来るだけ工程を省略し，また連続化するととは最も 有効な合理化の手段である・アメりカの工場で, 混打 綿機は殆んど One process 化され Opening 己 Picking 主目的とする機械の組合せも著しく簡素化されている。 従って緎維を Overwork してネップを作るようなととも ない.工場の混打綿機の代表的なセットの一例をあげる と第 1 図のようなものであ.る.Blending feeder 1 に対し て 4〜6俵供給してい.3. 徉って最低 12 俵から多い場合

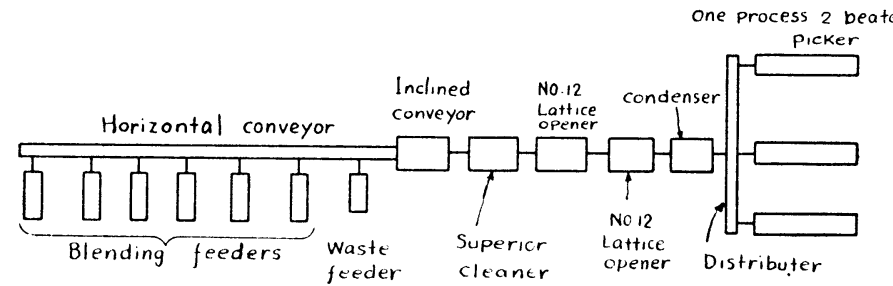

（第 1 忷）アメリカの混打綿機の一例

は60俵を混綿する. 練篠機は日本では 3 Passage が普 通であるが，アメリカの綿紡は殆んど 2 Passage に変一 ている. ちちろんそのため 1 頭台を 5 本ローラとして， スライバを 8 本フィードし 8 倍くらいのドラフトなかけ たり，るるいは最初に Lap winder t使って16本フ。 ードし, 次に Lap drawing た 14〜16 倍のドラフトを かけたりしている.そのドラフトの方法も, 最近のもの は4本のボットムローラの上に 3 本のトップローラ

(Three-over-four) あるいは 5 本の上に 4本 (Fourover-five) というょうに，纎維の Nip 在面て行うよう にしたり, またバックの 2 本を Metalic top roll とし て維持費を減したりしていろ。この纎維の Nip を線で なく面で行う方式は，長瀻維の場合特に良い結果をまげ てい.3.

粗紡機は 40's くらいまでは 1 紡式 (Simplex) で， これ以上の細番手になると 2 紡式である. 30 's 以上は Double roving で精紡機にフ セードする関係上, Simplex のドラフトをかなり増大する必要がある. このため4線 のローラ ドラフトを二つのドラフトゾーンに分けて, その中間にコンデンサを設けたり，またはエプロン装置 を設けたり，ローラを 5 線にしたりして調子良く操業し ている.ドラフトは10倍以上で，エプロンを備えたもの は Super draft rover と呼ばれ大体20倍前後である. 少 ない工程で良い糸を紡績することは重要な問題である から, 今後われわれはこれらの点を十分研究する必要が まる。
撚禾では双系はすべて合糸工程を省略している。また 先染めの経系や緯系老織機に仕掛けっ傾向があるが，チ 一ズまたはビームの形で染色する Package dyeing が大 規模に採用されている.これも綛繰りの省略と染色工程 の簡素化としてあげることができる。

（b）自動化と自動制御つ利用

アメリカの高い生產性と製品つ均一性は，作業の自動 化と自動制御に真うところが極めて大きい. Barber

Colman の Automatic spooler や Terrell Machine Co.

のボビンクリーナは我が国でもかなり採用されるよう になったが，アメリカの工場では既に普及化している。

Automatic quiller p Drawing in machine b広く使わ ne process 2 beater れ.る.目新しいものとしては,ラップ自動揚 げ装置, カードやコーマの自動ケンス替え 装置現われている。また私が見た South Carolina の Woodside Mill 怡化学瀻維 の専門工場であったが，ここでは混紡比率 む土1\%に確保さる Fiber meter (一種の Blending feeder) が調子・よく回っている の在見た・これも自動化の一つつ成功とみることができ 3 .

自動制御の面で全面的に採用されているつは，工場内 湿度つ Automatic contorol だる. Animal membrane が関係湿度によって伸縮する性犋を利用して, 霧吹きの 水老制御する方式が最も多く採用されている. 一方

Lithium chloride の電気抵抗が湿度によって变化する性 質を利用するものもある. 工場の湿度は混打綿及びカー ド50\%, 粗紡, 精紡 60〜65\%, 精紡で細番手のとき 55 〜60\%，織機室は 80〜85\%である・特にカードが 50\% に保たれていることによく注意を払う必要がある.我が 国でも工場内湿度の自動制御に成功なみつつあるが，今 後全般的に拡大して行く必要が女.と思う。温度の自動 制御をやっていた工場はただ一つしか見かけなかった。

自動制御が普及しているも一つの例は糊付機である。 乾燥シリンダまたは空気の温度, Size box の Level と 温度と粘度, 糸の水分率を Automatic にコントロールし ている. 糸のテンションもコントロールする.従って糊 付量の変動が少なくなり，金巾など 8〜10\%という少な い附着量で良好な結果を好げている.J-box や Steamer のような仕上加工機械では自動制御は不可欠つ附属装置 底っている.

(c) 高速度化

高速度化は近代交明の一大特徵であって，繊維機械も その例にもれず著しい高速度化を遂げた，従来コーマの 
Nip 数は每分 100 前後であったが, Whitin Machine Works のJ-2 コーマは $150 \mathrm{nip} / \mathrm{min}$ となり，生產高は 従来の 3 倍前後に達する. Saco-Lowell の Model-54 は $106 \mathrm{nip}$ で生產高は従来の 4.5 倍 (Head 数 12) であ る.アメリカのコーマは漸次これら高性能のものに更新 されつつある.粗紡機のスピンドルの回転数は我が国た も昔は高速運転をしていたが, 精紡機のドラフトの漸增 や Single rovingなどの関係から, 今日でかなり低速 になっていろ.アメリカの粗紡機は Inter で 800〜900

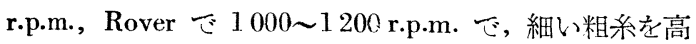
速運転で生產していろ.

ワインダの系速度は最低每分 $500 \mathrm{yd}$ た Abbott の

Automatic traveling spindle winder 悔分 600 650 yd, Barber Colman の Spooler 恃每分 $1200 \mathrm{yd}$ に達 する・私は一つの工場で $1250 \mathrm{yd}$ て運転しているの在 見た. 糊付機は 2 Cylinder slasher が最も多く使われて いる. 速度は普通 $40 \sim 50 \mathrm{yd} / \mathrm{min}$ て, 最低のものだ 每分 $30 \mathrm{yd}$, Uxbridge gentle air type slasher 悔分 $55 \sim 65 \mathrm{yd}$, 最高 $80 \mathrm{yd}$ にも達する. これは我が国の蒸気 圧が Cylinder type た $10 \mathrm{lb} /$ ロ, Hoi air type た $30 \mathrm{lb} / \square "$ 前後であ.るのに対して, Gentle air type の如 きは 100〜200 lb/ロ”というような高圧であることや， Squeezing roller が 2 対使われていてよく絞っている ことなどに因る。我が国でもさらにシリンダまわりの Covering の研究や Hot air の循環方式えの他の研究を する必要がある.織機では Draper, Crompton \& Knowles, Hunた などボビンチェンジ式の自動織機が多く 使われている. 44 in で $195 \mathrm{pick} / \mathrm{min}, 50$ in た 185 と いうように, 我が国の現状より少なくとも20\%高速て 運転されている. しかも 93〜96\%という高い效率であ る.これは前に述べたように原綿と原系自体がよいこ と, 準備で系の欠点が十分除去されているとと, テンシ ョンが均一で, 糊代が良好であるとと, 湿度が一定に制 御されていることなどに筫うところが大きいが，織機自 体項強な構造に設計されていて機構及び製作の精度も優 れていることが考觉られる. Atrantic City の展覧会で は Warner \& Swasey Snlzer の Weaving machine か 240 pick/min で回り，Saurer 織機も丁度 240 pick だ 回っているのを見た。

(d) Large package 化

Package 老大きくすることは人手を省く最も有効な手 段の一つで，我が国でもこの考学が着々採用されてい る.アメリカの工場ではラップの重量は 50〜60lb た 我が国より20〜30\%重い，そのため打綿機の Fiddle back 老改造すると同时に，我が国で一部やっているよ うに Antifriction rack のブレーキを Compressed air の Unit に取替えている. カードや練篠機などのスライ バケンスは最小 12 in だ，新しいるのは 14 in を採用 している.9〜10 inのものは既に影をひそめて見ること ができない. Single roving で精紡機に供給する太番手 の篠卷は,フル ボビンの直径 $6 \mathrm{in}$, リト $12 \mathrm{in}(6 \times 12)$ が最犬た，試験的にはリフト 13 in のbのが試作されて いた. Double roving で精紡機に供給する篠卷は, 粗紡 機老高速運転する関係もあって，Package はむしる小 さく, Simpl $\mathrm{x}$ は $5 \times 10$, 第 2 の粗紡機や Super draft rover は $4 \times 8$ のの多く見かけた.

精紡機ではリングの直径 3 in, リフト11〜12 in という ように大きな Package もむったが，工場の大部分の機 械は古いものの改造で，大体私が各工場を見て判断した Package の大きさは第 3 表の通りである・緯管系な精紡

(第 3 表) アメリカの精紡機の Package

\begin{tabular}{|c|c|c|}
\hline 番 手 & リングの直径(in) & リフト(in) \\
\hline $16 \sim 20$ & $21 / 2 \sim 21 / 4$ & $9 \sim 8$ \\
\hline $30 \sim 40$ & $2 \sim 13 / 4$ & $8 \sim 7$ \\
\hline $50 \sim 60$ & $13 / 4 \sim 15 / 8$ & $7 \sim 6$ \\
\hline $80 \sim 100$ & $15 / 8 \sim 11 / 2$ & $7 \sim 6$ \\
\hline
\end{tabular}

機で直接紡績する場合は，木管の全長 $8 \sim 8 \frac{3}{4}$ in の のが最も多かった. 従ってリフトは $6 \frac{1}{2} \sim 7 \frac{1}{4}$ in だ ングの直径は 11/4 13/8 in, 我が国より大体 $1 / 8$ in 太 いというのが実情である。しかしながら高級綿布の緯禾 はこの久点老除去する意味から卷返して使用するので， まれに木管の長さ 9 in のbのb見かけた。リングの Large package 化K伴って注意すべきととは, ボビンの 直径を適当に選ばねばならぬことである。卷取角度 (Angle of yarn pull) は $28^{\circ}$ にしている. またリング のフランジは 30's 附近を界にして細いものは No.1 ( N 型), 太いものはNo. 2 (W型) が多い. スピンドルテ ープは Spun Nylon から作ったものを多く使用してい そ. Whitin の技術者達之 Large package の限度につい て話合ったことがあるが，彼等も余り大きい Package は却って経済性をわるくするといっている・1 鉏当りの 機械代や床面積が大きくなり，モータの馬力も 300 錘で $20 \mathrm{P}$ というように迹方多く大きくなる。大体実際の 工場のリングは $2 \frac{1}{2}$ in どまりである.

$$
\text { コーンチーズの重量は我が国では } 1.0 \sim 1.5 \mathrm{lb,}
$$

Automatic spooler $2.5 \mathrm{lb}$ であるが, Barber Colman の最す新しいものは $6 \mathrm{lb}$ とも達する. ワーパース ビ 
一ム怕我が国の 24〜30 in 飞対して 38〜40 in になって いる・ウஃーバース ビームも我が国の 18〜20 in K詨 して 22〜30 in である. 織機の布の切り招ろしは, 我が 国ではカットマークに従って大体 $120 \mathrm{yd}$ (クロスロー ラの直径最大 8 1/2 in) であるが，アメリカでは 20 inく らいの直径になったとき切り扔るす. 加工工場へは直径 $2 \sim 3 \mathrm{ft}$ のロール卷で運搬する.ついでながら原禾専 門工場から織有工場へは Barber Colman のワーバでビ 一ムに卷き, ビームの形で運搬する.メリヤス系は $3 \mathrm{lb}$ のコーン卷にして60個な1個のボール紙の箱につめて送 っている.

(e) ドラフトローラ

最近我が国でも Synthetic cotやApronをかなり使 うようになったが,アメリカの工場では殆んどこれに変 ってしまっている。また Loose boss roll とはボールま たはローラベアリングを採用し， Solid roll には Oilless metal またはナイロンを使っている・ローラ スタンドのメタルも Oilless metal やボール ベアリン グを使う・バニッシングや給油のためのローラ替えが殆 えど不必要であるから, ただ専門工が Rollpicker を使 ってローラまわりを定期的に掃除していらだけであ.る。 我が国だす Leather roll や apron の Synthetic 化を さらに推進する必要があると思う。

(f) 掃除の機械化

アメリカの紡績では塵突は既に姿を消し, Bag を使 5 Air filter や Return air condenser がこれに变って い马・室内宾気老排気する必要がないときは空気学循環 させて熱の損失や湿度の变動を防いでいる。徉って塵突 の掃除々いうような仕事は皆舆である. カードのテーカ イン下の落綿やトップの内側はV Vacuum dust remover を使って手際よく吸取ってい㟔が，我が国で果して経済 性があらかどうか疑閏である・精紡機の Pneumafil ま たは Pneumatic clearer, 精紡, 粗紡カード, 仕上室な どの風綿の堆積を防ぐ Traveling fan, 同じく精紡機の 台下に Fan を走行させる Monocleaner など掃除の穖 械化が可なり徹底している.中でも Traveling fan は 最も普及化していて有效に働いている.定期掃除や織機 の後まわりの掃除には Compressed air 壳多く使ってい ろ. 我が国の作業分析によれば，40's で粗紡の台持工 はその時間の 15〜22\%を挦除にむて, 精紡の台持と玉 揚は約 $30 \%$ 掃除にあてている。これら在えるとき 担除の機械化は，今後我が国て真剱け採りるげねばなら ぬ問題の一つであろ.

アメリカの綿紡は機械設備の面て以上の特徵をもって
いるが，その改造更新にあたっては最す效果のあるるの から手をつけている・カードの集団運転はとのままにし てで Automatic spooler は睡大するといったやり方 である・さきに述べた Dean Campbell のととろでは, 農務省の後援て， カードのテーカインシリンダを高速 回転して品質を落さず生產を上げる方法を研究した。こ の方法は我が国にも紹介されて種々検討されているが， アメリカの実際の工場はまだまだ採り大れていない。そ れはこの方法がわるいからではなく, 彼等が 1 世紀以上 にわたってやって来た方式を变更するには余程の実証が 要るわけで，彼等の性格の Conservative な一面を物語 っているように思われる・

\section{週期や程度の限界に関する考え}

定期掃除やカードの磨針の週間，あるいい品質管理の 程度といったような事柄については, 必要にして最小の 限界を深く研究し, 形式に拘泥せず少しの無駄すなくや っている. 混打綿機のセット中の機械の数や練篠機の Passage の数にしても, これ以上穖械や工程を増しても 結果が殆んど変らない, 変ってもほんの僅少であるとい うような場合は敢えて増加しない万全を期するために 徒らに手数をかけることは,労多くして效少なしとして， 限界を研究してある点で我慢する。この考え方があらゆ る面に現われている・品質管理にして子経済点を考兄て 採り大れ，混打綿工程のような要所はあくまで厳格な管 理を行い，をはスライバや粗糸のゲレンなど時々チェ ックするだけにとどめる．として最終製品はまた市場性 在十分考慮に大れて検査をするというやり方である。

な拈週期について面白く感じたことは，綿紡のような 場合でもトラベラを定期的に一斉に取替える。例えば $120 \mathrm{hr}$ ごとに取替える・徉ってトラベラが不覞則に飛 散して糸切れになることがなく，また飛散しない子て もトラベラが磨耗して異常なテンションひいては糸 切れの原因となるようなとともない。一般にアメリカの 工場の精紡杀切れは 20 授算 1 錘量 $0.73 \mathrm{lb}$ 前後の運 転て 400 錘 $1 \mathrm{hr}$ 当り 8〜 12本の間にある.とのくら いの系切れに保つには余程細かい注意を払う必要が女 そ. 一つつ給油の週期であるが, 全般的にみて Centralized lubricating system を使う傾向にある。また高 速回転には Antifriction bearing, 低速には Oilless metal や Bottle oiler (Synthetic の bottle) 在使う. 止むを得ず手で注油する場合です，良質の㛇を使って注 油の週期をてきるだけ延展するようにしている。 


\section{公正な仕事の割当と高率公正な稹金支給}

工場管理の F. W. Taylor 点出した国だけ女って, 仕 事の割当は.Tine study その他の科学的な職務分析法 によって公平正確に行っている。賃金もまた公正心高率 に交払われている。注目すべきことは，作業が同一であ れば男女とも同一賃率て，穓金は仕事の量によって決定 され，男女の別や年令，勤続年数には無関係なことて

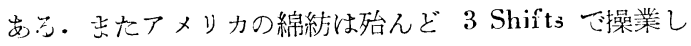
ているが深夜の Shift К歩なつけることは殆んどない。 つけているところたも 5 \%位てもる．要するに取入は全 く技倆々働きの量によって決定され，働かざれば金儲け に年らいということに徹底している。

\section{管理者の熟意と精神の徹底}

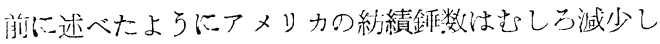

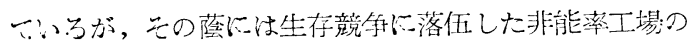
䦌鎖や南部への移駐志ど興亡の歴史が数多く秘められて いに湋いない，従っ一上は社長から下は労務者の1人

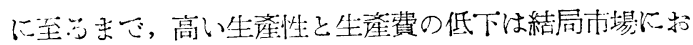

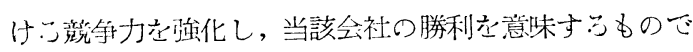
むっーひいては目分の生活の安定と生活水潗の间上に 心゙こと㐫心から悟っているように私は感じた。現在最

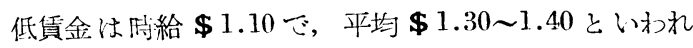

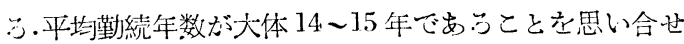
て，収大に大した差な゙なく，しか子彼等が上下然々とし

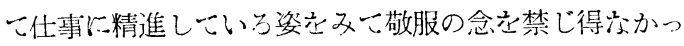

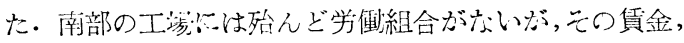
社宅この他の福利施設など北部以上に恵きれた労働条件 交受しているょうに感じた。

\section{研究の分業化}

瀻維機械や附属装置のメ一力, 糊材料, 染料乞の他 Textile chemicals のメーカはそれぞれ立派な研究施設 と優秀心技術陣老もっていら。气してえれぞれの面で指 導的な地位老確保している.我が国のように紡續各社が これぞれ独自の設計を発注したり，むるいは独自の陮合 交注交したりするようなことがなく，メーカに維大な信 頼を置いて安心してえの製品を使っているというのが夷

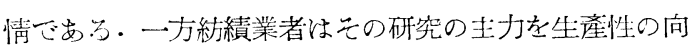
上や品質の改善, 新製品の開拓といらような本来の聥務 に結集している. Dan River Mill の如きは48台の試 織用織機上試騃用の紡續加工の一貫した設備なるち, 種 トの澵しいデザインの織物卒研究したり, 新しい加工法 亦研究したりしていた。このように研究の面こも分業化 冷確立し，これぶれの面に日進月歩の進歩齐みせ一い ๖.この点我が国のメ一カの奮起主希望するとともに, 我ハの研究のめり方も反省してみう必要がまる。

要すうにアメリカの綿業技術は上上のように物心画面 の発澾の栖致に近づきつつもるということができ。こ れ以上の飛躍的な進歩は，革命的尖発明心すない限り望 さべくもない。これにひきか光, 我が国の綿業はアメり 力に比して遥かに低位にあるから, 今後のやり方如何に よっては，まだまだ伸長の余地が残されている。特にわ れわれ技術者は大きな責任痛感す引次第であ.る我が 国の綿紡は，これまで設備の増没と拡充に多くの資金を

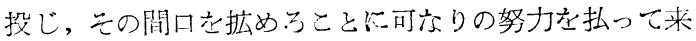
た。晓心設倫は過剩の状態に達し, 却って業界を不安に 陷しいれこいるほどである。令後はアメリカの綿業の特

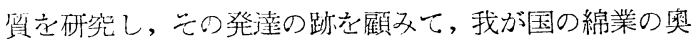
行き交深め, 真に笑力の女.企業体たらしめる方向に物

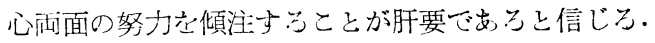

